\title{
Effective Physical Education Distance Learning Models during the Covid-19 Epidemic
}

TAnja Petrušič ${ }^{\star 1}$ And Vesna ŠTemberger ${ }^{2}$

$\approx$ The Covid-19 epidemic has had a strong impact on the implementation of the entire educational process due to the closure of public life and schools. Physical education (PE) teachers were faced with the challenge of conveying at a distance the learning content that they would otherwise teach in the sports hall. Our research aimed to determine which PE distance learning models proved to be the most effective during the epidemic, resulting in a high level of pupils' activity despite participation from home. In the process of data collection, we included $33 \mathrm{PE}$ distance learning lessons at the lower secondary level, where six pupils ( 3 girls and 3 boys) wore accelerometers in each lesson ( $n=198$ pupils). The results showed that the most effective model was the flipped learning teaching model, where pupils were given an overview in advance of the different forms of teacher video recordings. Then they also actively participated with their ideas in the performance of the online lesson. A statistically significantly less efficient version of the flipped learning teaching model had prepared interactive assignments and games. This was followed by a combination of online frontal teaching with station work and frontal teaching. The least effective was independent work carried out by the pupils according to the instructions prepared by the teacher. Although the two flipped learning teaching models were the most effective in terms of exercise intensity, it is very difficult to implement them in practice because they require too much teacher time.

Keywords: Covid-19, online teaching, physical education, teaching models, effectiveness

$1{ }^{\star}$ Correspondig Author. Faculty of Education, University of Ljubljana, Slovenia; tanja.petrusic@pef.uni-lj.si.

2 Faculty of Education, University of Ljubljana, Slovenia. 


\section{Učinkoviti modeli poučevanja športa na daljavo med epidemijo covida-19}

Tanja Petrušič in Vesna Štemberger

$\propto$ Epidemija virusa covid-19 je zaradi zaustavljanja javnega življenja in zapiranja šol močno vplivala na izvedbo celotnega pedagoškega procesa. Učitelji športa so bili postavljeni pred izziv, kako učne vsebine, ki jih sicer izvajajo v telovadnici, poučevati na daljavo. Namen naše raziskave je bil ugotoviti, kateri modeli poučevanja športa na daljavo so se med epidemijo izkazali kot najučinkovitejši, tj. z rezultatom visoke aktivnosti učencev kljub sodelovanju od doma. V proces pridobivanja podatkov smo vključili 33 na daljavo izvedenih učnih ur športa na predmetni stopnji, znotraj katerih je vsako učno uro šest učencev (tri deklice in trije dečki) nosilo merilnike pospeška ( $n=198$ učencev). Rezultati so pokazali, da se je kot najučinkovitejši model pojavljal obrnjen model poučevanja, pri katerem so učenci vnaprej dobili v pregled različne oblike učiteljevih videoposnetkov, nato pa na učni uri, ki je bila izvedena na daljavo, aktivno sodelovali pri izvedbah tudi s svojimi idejami. Statistično značilno manj učinkovita različica obrnjenega modela poučevanja je bila $z$ vnaprej pripravljenimi interaktivnimi nalogami in igrami. Sledila sta ji kombinacija na daljavo izvedenih učnih oblik frontalnega poučevanja $\mathrm{z}$ delom po postajah in frontalno poučevanje. Kot najmanj učinkovito je bilo samostojno delo učencev po učiteljevih pripravljenih navodilih. Čeprav sta se oba obrnjena modela poučevanja izkazala kot najučinkovitejša glede intenzivnosti aktivnosti učencev med učnimi urami, ju je težko vpeljevati v prakso, saj načrtovanje in izpeljava zahtevata precej učiteljevega časa.

Ključne besede: covid-19, poučevanje na daljavo, šport, modeli poučevanja, učinkovitost 


\section{Introduction}

The Covid-19 coronavirus epidemic broke out in the Chinese province of Hubei in late 2019 but spread rapidly to many countries around the world in the first half of 2020 due to high infection rates (Velavan \& Meyer, 202O), leading to the lockdown of public life and subsequent school closure (Petretto et al., 2020; Viner et al., 2020); Slovenia was no exception. Even though children were exposed to a significantly low risk of developing the disease or long-term complications after recovering from the infection (Qiu et al., 2020), they were deemed to be carriers of the virus to more vulnerable groups; so, their education was fully transferred to the online environment (Quezada et al., 2020). Such a change in work methods had a strong impact on the implementation of the entire pedagogical process. In a very short time, Physical Education (PE) teachers were compelled to find new ways to teach PE-related learning content, which otherwise takes place in a sports hall, at a distance (Varea \& Gonzáles-Calvo, 2020), as effectively as possible (achieving the result of moderate and high-intensity physical activity of the pupils). Adaptation was especially challenging with types of content that require a large space (sports hall) and forms of in-class grouping that encourage socialisation among pupils (e.g., group work) (Richards et al., 2020). Distance learning with knowledge and use of various technologies enabled teaching of almost all PE-related content; thus, it was only necessary to find the most suitable approach and form of within-class grouping for each type of learning content to enable pupils to achieve their learning goals with a high activity level while maintaining a positive learning environment during PE distance learning lessons (Filiz \& Konukman, 2020). Teachers were able to teach PE-related content at a distance through online classes via live-streaming, recorded videos, movement diaries, assignments for pupils, online materials with lessons with practical and theoretical content, online questionnaires or distance-learning programmes with suggestions for physical activity from home (ibid.). In addition to selecting a suitable digital tool based on learning content for distance learning, teachers also had to select a suitable form of within-class grouping. Teachers usually only use one form of within-class grouping per one hourly PE lesson when teaching in the sports hall, but to increase the pupils' activity, they could also use a combination, for example, the first part of the frontal lesson work (in queues) and then group work (at stations) (Videmšek \& Pišot, 2007). Teachers can also use the same combination to teach PE at a distance on online platforms such as Zoom, Microsoft Teams, Blackboard and Canvas (Guraya, 2020), which allow pupils to be divided into 'rooms' or 'groups'.

Additionally, a different virtual approach to teaching, namely the flipped learning teaching model (Chick et al., 2020), may also improve the pupils' learning 
experience. In comparison to the traditional teaching model, where the focus is on the teacher and their explanations (Betihavas et al., 2016), the flipped learning teaching model focuses on the pupils' ability to acquire new knowledge and understanding on their own through mutual collaboration (Sohrabi \& Iraj, 2016). In this form of work, pupils receive material in advance in the form of various videos of practical performances, recorded lessons or short assignments, followed by a short explanation or review of the content during the lesson itself. Afterwards, the teacher divides the pupils into smaller groups. These groups discuss their newly acquired knowledge and jointly work out a specific problem-solving task related to the learning content received in the pre-prepared material (Guraya, 2020). Teachers can use the flipped learning teaching model for PE-related content under regular conditions, in which the pupils' lessons and group work take place effortlessly in a sports hall without social distancing, as well as for distance teaching, in which pupils receive pre-prepared material via online classrooms, e-mail and so on, working in small groups, during the lessons conducted via the above-mentioned online platforms (ibid.).

Distance learning overcomes the limitations of space and time (Buschner, 2006; Kooiman, 2017, Mohnsen, 2012; Mosier, 2013; Rhea, 2013); thus, not much research exists on effective approaches to teaching $\mathrm{PE}$ at a distance to achieve a sufficiently high moderate and high-intensity of pupils' activity during the lessons themselves. Moreover, as the lockdown of public life during the first wave of the Covid-19 epidemic happened completely unexpectedly, at that time, most teachers stepped into this new field of distance learning PE teaching unprepared. Due to the inability to predict the duration of such a work form (depending on the country's epidemiological picture), it is apparent that PE teachers need help in preparing effective distance learning lessons based on recent research findings that are specifically related to the current state of the epidemic, with the same restrictions and educational opportunities.

Therefore, in this research, we posed the following research question:

- Which PE distance learning models are most effective during the Covid-19 epidemic, resulting in a high level of pupil activity despite all limitations and participation from home?

\section{Method}

The research was conducted through an action research approach.

To determine which PE distance learning models are the most effective during the Covid-19 epidemic for pupils to achieve high levels of activity during the lessons, we used a cause-related, non-experimental work method. 


\section{Participants}

The action research included 33 distance learning PE lessons at the subject level of one primary school, which were taught individually alternately by two PE teachers. Pupils from Grades 6, 7, 8 and 9 (average age: 12.5 years old) were included. There was an average of 25 pupils in each class, but for the needs of our research, only six pupils ( 3 girls and 3 boys) were randomly selected; only those pupils who, based on the results of their PE report card, had developed motor skills within the average of Slovenian pupils of the same age, and whose parents signed a permit to participate in the research, were included in the selection. These pupils wore accelerometers during each lesson, which showed us exactly how many minutes and seconds were spent inactively and how many were spent in low, medium, and high-intensity activities. In total, the activity level during distance learning lessons was measured with 198 pupils (i.e., 99 girls and 99 boys).

\section{Research design}

The action research aimed to discover which distance learning models proved to be most effective during the Covid-19 epidemic. The research was conducted during the closure of schools in the second wave, in October and November 2020. In October and November, we carried out an observed and monitored pedagogical process of the $\mathrm{PE}$, in which we made alterations with different teaching models (we tested five different distance learning models for $\mathrm{PE}$ ), and the preparations for implementation began about a month before the start of teaching, in September 2020.

\section{Table 1}

Five PE distance learning models

\begin{tabular}{|c|c|c|c|c|}
\hline Model 1 & Model 2 & Model 3 & Model 4 & Model 5 \\
\hline Individual work & Frontal teaching & $\begin{array}{l}\text { Combination of } \\
\text { frontal teaching } \\
\text { and group work }\end{array}$ & $\begin{array}{l}\text { Flipped learning } \\
\text { teaching model } \\
\text { (with interactive } \\
\text { assignments and } \\
\text { games) }\end{array}$ & $\begin{array}{c}\text { Flipped learning } \\
\text { teaching model } \\
\text { (with videos) }\end{array}$ \\
\hline
\end{tabular}

In Model 1 (independent teaching), pupils were given instructions in advance with detailed descriptions of movements, equipped with sketches of the correct manner of performance and with the number of repetitions for performances of each element and a record of the approximate duration of the exercise. 
In Model 2 (frontal teaching), the teacher conducted a distance learning PE lesson with the pupils by signing in on the Zoom platform through computers/mobile phones when the lesson was scheduled that day. Then they performed the elements by watching a direct demonstration and listening to the teacher's explanation and then repeating the exercises themselves.

In Model 3 (a combination of frontal teaching and group work), the work was organised in the same way as in Model 2, except that the teacher combined two different forms of within-class grouping during the lesson and thus, in addition to frontal teaching, group learning was also used, and the pupils were divided across the Zoom platform's rooms. Then further work was done around the stations in the sports hall.

In Models 4 and 5 (the flipped learning teaching model (with interactive assignments and games) and the flipped learning teaching model (with videos)), pupils were given pre-prepared material, which they had to process the day before the scheduled lesson. For example, in Model 4, pupils were given interactive assignments and games that predicted the content to be learned the next day when correctly completed. Interactive assignments and games, such as online puzzles with a picture of the correct performance of a certain element, sorting the pictures correctly in the correct order of movement, naming of movements by connecting words to the pictures and so on, and performing the movements of the elements presented along with the solved assignments.

In Model 5, pupils were not given interactive assignments and games in advance but prepared videos featuring demonstrations of the elements to be learned in the next lesson. Upon observing the demonstration, they had to try to perform the elements themselves. In Models 4 and 5, the material also contained one problem-solving activity that the pupils had to consider and then solve together in small groups in the next day's PE lesson. Thus, the sum of minutes in moderate and high-intensity activity by pupils in Models 4 and 5 was the result of both parts of the lesson (on the day of the scheduled lesson and the day before, when working with material or solving assignments/games and imitating the movements on video).

The teaching and observation of PE lessons were carried out for two weeks and two days, every working day from Monday to Friday (content of the lessons: athletics, natural forms of movement, games and general conditioning). Each day, we taught and observed two or three PE lessons, including at least one break in the length of an hourly lesson, as we had to replace and disinfect the gauges and straps and then place them (without making personal contact) in front of the door of the pupils whose activity level was to be measured in the following lesson. During the handover, the gauges were inserted 
into pockets on the straps, which could easily be attached to the body (so the pupils could fasten them around the waist over the T-shirt so that the gauge was on each individual's side during the lesson. Then the activity level of the six selected pupils (three girls and three boys) was measured. In four of the five types of distance PE models (independent work was conducted differently), lessons were taught individually by two alternating PE teachers. Via the Zoom online platform, they were observed by a PE didactics assistant who monitored the pupils' activity level and prepared diary records. In the independent work model, pupils could perform the work at any time during the day as they received work instructions and gauges in advance; they only needed to note the start time and finish time for the gauge data reading and enter it into the diary record. Based on these diary records, we completed the preparation of lessons and materials for pupils while entering the changes in the pedagogical process.

The purpose of the research was explained in writing to the parents of the pupils participating; complete anonymity was guaranteed for all.

\section{Measuring instruments}

Two different measuring instruments were used for the research:

- 6 accelerometers MMOXX1.07 (USB waterproof physical activity sensor $35 \times 35 \times 10 \mathrm{~mm}$ ), by which we measured the pupils' activity intensity level;

- $\quad$ Diary records.

The accelerometers measured the pupils' activity intensity level during the lessons: how many minutes they spent in low ( $\left.<3 \mathrm{METs}^{3}\right)$, moderate $(3-<6 \mathrm{METs})$, and high-intensity activity (> 6 METs) (Colley \& Tremblay, 2011), which was also our main indicator of the effectiveness of lessons according to the individual model tested during a particular lesson. In addition, we used unstructured instruments (diary records) to monitor and record the course of the entire action research. For each model we tested, we had a separate diary in which we recorded before each lesson what we needed for the implementation (what kind of materials are required for the pupils and which programmes will be used to prepare it), how the pupils respond during the lesson and how they participate. After the lesson, we described the material needed and used during the lesson, the length of the lesson, recommended changes for the next lesson, and most importantly: the level of pupils' activity or how many minutes they spent in moderate high-intensity activity.

3 MET: Metabolic equivalent of task: The amount of oxygen consumed while sitting at rest and is equal to $3.5 \mathrm{ml} \mathrm{O}_{2}$ per $\mathrm{kg}$ body weight $\times \mathrm{min} /$ one MET corresponds to an energy expenditure of $1 \mathrm{kcal} / \mathrm{kg} / \mathrm{hour}$. 


\section{Statistical Analysis}

The acquired data were processed with the IBM SPSS Statistics 22 software for MS Windows. We first calculated the basic statistics of pupils' activity levels for each model that we studied. After that, we used the Kruskal-Wallis test to check whether there were statistically significant differences between the individual distance learning models in the number of minutes spent by pupils in moderate and high-intensity activity and then used the Mann-Whitney test to check whether statistically significant differences occurred among the models, (each model out of the five studied was compared with each of the others) and which PE distance learning models were statistically significantly the most effective according to our quality indicator (pupils' activity level).

\section{Results}

Table 2 reveals data on the number of minutes spent by pupils in 33 taught and observed PE lessons in moderate and high-intensity activity. The data in the table are separated according to the individual PE lesson model used and within the model according to class.

Table 2

Basic statistics on the sum of minutes of moderate and high-intensity activity of pupils per each type of $P E$ distance learning model

\begin{tabular}{|c|c|c|c|c|c|c|}
\hline $\begin{array}{l}\text { Type of distance } \\
\text { PE model: }\end{array}$ & & $\begin{array}{l}\mathrm{N} \\
\text { (no. of teaching } \\
\text { hours) }\end{array}$ & $\begin{array}{l}\text { Minimum } \\
\text { (minutes) }\end{array}$ & $\begin{array}{l}\text { Maximum } \\
\text { (minutes) }\end{array}$ & $\begin{array}{c}\text { Mean } \\
\text { (minutes) }\end{array}$ & SD \\
\hline \multirow{5}{*}{$\begin{array}{l}\text { Model 1: } \\
\text { Individual work }\end{array}$} & $6^{\text {th }}$ grade & 3 & 4.03 & 5.42 & 4.59 & .49 \\
\hline & $7^{\text {th }}$ grade & 2 & 3.00 & 5.45 & 4.33 & .99 \\
\hline & $8^{\text {th }}$ grade & 1 & 3.14 & 4.42 & 4.18 & .64 \\
\hline & $9^{\text {th }}$ grade & 1 & 4.09 & 4.27 & 4.18 & .07 \\
\hline & Total & 7 & 3.00 & 5.45 & 4.34 & .70 \\
\hline \multirow{4}{*}{$\begin{array}{l}\text { Model 2: } \\
\text { Frontal teaching }\end{array}$} & $6^{\text {th }}$ grade & 7 & 4.32 & 9.45 & 7.18 & 1.36 \\
\hline & $8^{\text {th }}$ grade & 3 & 8.05 & 11.08 & 9.23 & .88 \\
\hline & $9^{\text {th }}$ grade & 1 & 8.53 & 10.21 & 9.44 & .66 \\
\hline & Total & 11 & 4.32 & 11.08 & 8.09 & 1.69 \\
\hline \multirow{4}{*}{$\begin{array}{l}\text { Model 3: } \\
\text { Combination of } \\
\text { frontal teaching } \\
\text { and group work }\end{array}$} & $6^{\text {th }}$ grade & 1 & 15.46 & 16.38 & 16.05 & .32 \\
\hline & $7^{\text {th }}$ grade & 2 & 13.25 & 14.30 & 14.18 & .38 \\
\hline & $9^{\text {th }}$ grade & 2 & 14.13 & 15.47 & 15.32 & .46 \\
\hline & Total & 5 & 13.25 & 16.38 & 15.19 & .95 \\
\hline
\end{tabular}




\begin{tabular}{|c|c|c|c|c|c|c|}
\hline $\begin{array}{l}\text { Type of distance } \\
\text { PE model: }\end{array}$ & & $\begin{array}{l}\mathrm{N} \\
\text { (no. of teaching } \\
\text { hours) }\end{array}$ & $\begin{array}{l}\text { Minimum } \\
\text { (minutes) }\end{array}$ & $\begin{array}{l}\text { Maximum } \\
\text { (minutes) }\end{array}$ & $\begin{array}{c}\text { Mean } \\
\text { (minutes) }\end{array}$ & SD \\
\hline \multirow{4}{*}{$\begin{array}{l}\text { Model 4: } \\
\text { Flipped learning } \\
\text { teaching model } \\
\text { (with interactive } \\
\text { assignments and } \\
\text { games) }\end{array}$} & $7^{\text {th }}$ grade & 1 & 20.45 & 21.30 & 21.06 & .31 \\
\hline & $8^{\text {th }}$ grade & 3 & 21.50 & 24.49 & 23.19 & 1.03 \\
\hline & $9^{\text {th }}$ grade & 1 & 21.33 & 22.13 & 22.06 & .34 \\
\hline & Total & 5 & 20.45 & 24.49 & 22.22 & 1.10 \\
\hline \multirow{4}{*}{$\begin{array}{l}\text { Model 5: } \\
\text { Flipped learning } \\
\text { teaching model } \\
\text { (with videos) }\end{array}$} & $7^{\text {th }}$ grade & 1 & 26.01 & 27.09 & 26.48 & .48 \\
\hline & $8^{\text {th }}$ grade & 3 & 27.57 & 29.42 & 29.25 & .49 \\
\hline & $9^{\text {th }}$ grade & 1 & 27.14 & 28.30 & 28.12 & .53 \\
\hline & Total & 5 & 26.01 & 29.42 & 28.15 & 1.07 \\
\hline
\end{tabular}

In Model 1 (individual work), pupils' average sum of minutes in moderate and high-intensity activity was the lowest, at 4.34 minutes. The lowest score for this model was 3.00 minutes, and the highest was 5.45 minutes. Model 1 was followed by Model 2 (frontal teaching) with an average value of 8.09 minutes (lowest result: 4.32 minutes, highest result: 11.08 minutes) and Model 3 (a combination of frontal teaching and group work) with an average value of $15.19 \mathrm{~min}$ utes (lowest result: 13.25 minutes, highest score: 16.38 minutes). Pupils achieved the highest sum of minutes in moderate and high-intensity activity in Models 4 (the flipped learning teaching model in combination with interactive assignments and games) and 5 (the flipped learning teaching model in combination with videos), where the minutes of their activity were added both days when performing pre-acquired assignments and during the lesson itself). For Model 4, the average value was $5.10+17.12$ minutes (lowest result: $4.13+16.32$ minutes; highest result: $6.08+18.41$ minutes), and for Model 5 as much as $8.09+20.06$ minutes (lowest result: 7.12+18.49 minutes, highest result: $9.27+20.15$ minutes).

\section{Table 3}

Differences between PE distance learning models in terms of effectiveness

\begin{tabular}{|c|c|c|c|c|c|c|}
\hline & $\begin{array}{l}\text { Type of distance PE } \\
\text { model }\end{array}$ & $\begin{array}{l}\mathrm{N} \\
\text { (no. of } \\
\text { teaching } \\
\text { hours) }\end{array}$ & $\begin{array}{l}\text { Mean } \\
\text { Rank }\end{array}$ & $\begin{array}{l}\text { Chi- } \\
\text { Square }\end{array}$ & df & $\begin{array}{l}\text { Asymp. } \\
\text { Sig. }\end{array}$ \\
\hline \multirow{6}{*}{$\begin{array}{l}\text { Activity intensity } \\
\text { level } \\
\text { (sum of minutes } \\
\text { in moderate and } \\
\text { high-intensity) }\end{array}$} & Individual work & 7 & 4.34 & \multirow{6}{*}{30.013} & \multirow{6}{*}{4} & \multirow{6}{*}{.000} \\
\hline & Frontal teaching & 11 & 8.09 & & & \\
\hline & $\begin{array}{l}\text { Combination of frontal } \\
\text { teaching and group work }\end{array}$ & 5 & 15.19 & & & \\
\hline & $\begin{array}{l}\text { Flipped learning teaching } \\
\text { model (with interactive } \\
\text { assignments and games) }\end{array}$ & 5 & 22.22 & & & \\
\hline & $\begin{array}{l}\text { Flipped learning teaching } \\
\text { model (with videos) }\end{array}$ & 5 & 28.15 & & & \\
\hline & Total & 33 & & & & \\
\hline
\end{tabular}


Table 3 shows the values of the Kruskal-Vallis test, which was used to check whether there were statistically significant differences between the individual types of distance PE models used. It is evident from the Table that statistically significant differences $(\mathrm{p}<.001)$ appear among the individual models concerning the achieved levels of pupils' activity.

Next, we used the Mann-Whitney test to analyse which models have statistically significant differences or which models are statistically significantly more effective than others in terms of the intensity level of pupils' physical activity (Table 4).

\section{Table 4}

Differences between combinations of lessons in each PE distance learning model in terms of effectiveness

\begin{tabular}{|c|c|c|c|c|c|}
\hline & Distance PE Model & $\mathbf{N}$ & $\begin{array}{l}\text { Mean } \\
\text { Rank }\end{array}$ & $\begin{array}{c}\text { Mann- } \\
\text { Whitney U }\end{array}$ & $\begin{array}{l}\text { Asymp. } \\
\text { Sig. } \\
\text { (2-tailed) }\end{array}$ \\
\hline \multirow{20}{*}{$\begin{array}{l}\text { Pupils' intensity } \\
\text { level } \\
\text { (sum of minutes } \\
\text { in moderate and } \\
\text { high-intensity } \\
\text { activity) }\end{array}$} & Individual work & 7 & 4.34 & \multirow{2}{*}{1.000} & \multirow{2}{*}{.001} \\
\hline & Frontal teaching & 11 & 8.09 & & \\
\hline & Individual work & 7 & 4.34 & \multirow[b]{2}{*}{.000} & \multirow[b]{2}{*}{.004} \\
\hline & $\begin{array}{l}\text { Combination of frontal teaching and group } \\
\text { work }\end{array}$ & 5 & 15.19 & & \\
\hline & Individual work & 7 & 4.34 & \multirow[b]{2}{*}{.000} & \multirow[b]{2}{*}{.004} \\
\hline & $\begin{array}{l}\text { Flipped learning teaching model (with interac- } \\
\text { tive assignments and games) }\end{array}$ & 5 & 22.22 & & \\
\hline & Individual work & 7 & 4.34 & \multirow{2}{*}{.000} & \multirow{2}{*}{.004} \\
\hline & Flipped learning teaching model (with videos) & 5 & 28.15 & & \\
\hline & Frontal teaching & 11 & 8.09 & \multirow[b]{2}{*}{.000} & \multirow[b]{2}{*}{.002} \\
\hline & $\begin{array}{l}\text { Combination of frontal teaching and group } \\
\text { work }\end{array}$ & 5 & 15.19 & & \\
\hline & Frontal teaching & 11 & 8.09 & \multirow[b]{2}{*}{.000} & \multirow[b]{2}{*}{.002} \\
\hline & $\begin{array}{l}\text { Flipped learning teaching model (with interac- } \\
\text { tive assignments and games) }\end{array}$ & 5 & 22.22 & & \\
\hline & Frontal teaching & 11 & 8.09 & \multirow{2}{*}{.000} & \multirow{2}{*}{.002} \\
\hline & Flipped learning teaching model (with videos) & 5 & 28.15 & & \\
\hline & $\begin{array}{l}\text { Combination of frontal teaching and group- } \\
\text { work }\end{array}$ & 5 & 15.19 & \multirow{2}{*}{.000} & \multirow{2}{*}{.009} \\
\hline & $\begin{array}{l}\text { Flipped learning teaching model (with interac- } \\
\text { tive assignments and games) }\end{array}$ & 5 & 22.22 & & \\
\hline & $\begin{array}{l}\text { Combination of frontal teaching and group- } \\
\text { work }\end{array}$ & 5 & 15.19 & \multirow[t]{2}{*}{.000} & \multirow[t]{2}{*}{.009} \\
\hline & Flipped learning teaching model (with videos) & 5 & 28.15 & & \\
\hline & $\begin{array}{l}\text { Flipped learning teaching model (with interac- } \\
\text { tive assignments and games) }\end{array}$ & 5 & 22.22 & \multirow{2}{*}{.000} & \multirow{2}{*}{.009} \\
\hline & Flipped learning teaching model (with videos) & 5 & 28.15 & & \\
\hline
\end{tabular}


Table 4 shows the results of the Mann-Whitney test, which was used to check which distance PE models have statistically significant differences concerning pupils' activity. Each model used was compared with each other, and statistically significant differences having a risk of less than .05 are marked in italics in the table. Table 4 shows that statistically significant differences in the achievement of high-intensity activity occur among all five distance PE models tested (the models in Table 4 are ranked from least to most effective). This tells us that each of the studied models is statistically significantly more effective than the previous one in terms of achieving the highest possible medium and high intensity of pupil activity during lessons; the least effective model was individual student work, followed by statistically significantly more effective results between each frontal teaching, combined frontal teaching and group work, flipped learning teaching model (with interactive assignments and games) and flipped learning teaching model (with videos).

\section{Discussion}

The most important contribution of the above-mentioned research is gaining insight into which distance teaching models can most effectively impact the higher achieved levels of moderate and high-intensity activity in distance PE lessons. Since the Covid-19 epidemic has temporarily altered the school teaching system (Petretto et al., 2020; Viner et al., 2020), distance learning is currently unavoidable, bringing a host of obstacles, including a lack of space, poor visibility of direct demonstrations, the teachers' inability to protect and assist the pupils' performances of elements, lack of tools, props, and similar issues. Nevertheless, teachers must teach pupils PE lessons in compliance with all restrictions; thus, they should select the model that would best allow them to transfer knowledge to pupils concerning the content they want to teach, concerning the barriers brought on by distance teaching of such content and, at the same time, to consolidate or transmit new learning material and thus enable a high level of pupils' activity in the most diverse and interesting way possible.

The research provided an answer to the research question of which PE distance learning models were most effective during the Covid-19 epidemic, resulting in a high level of pupil activity despite all limitations and participation from home. Each individual studied model brought both advantages and disadvantages or limitations in teaching due to the declared epidemic. Therefore, in the following, we conducted a more detailed analysis of the comparisons between each one. 
In comparison with the other four models studied, individual work proved to be the least effective distance learning model for pupils ( $p=.001$; .004; .004; .004). With this model, pupils were given instructions in advance for individual work at home or exercise in nature. Considering the average number of minutes spent in moderate and high-intensity activity, very low values were achieved here ( $M=4.34$ minutes). From the obtained results, we could conclude that without the teacher's direct supervision, not all pupils performed the elements qualitatively and correctly. Based on interim results and diary records of their obligations, we tried to increase the duration of independent work and the number of repetitions during the research, but their minutes spent in moderate and high-intensity activity did not improve statistically significantly. This model brought advantages such as unlimited space and an unnecessary internet connection, as the elements could be performed outdoors, and disadvantages such as insufficient teacher supervision, poor performance and perhaps a poorer understanding of instructions and poorer performance of required exercises without direct demonstration. In this regard, Goudas \& Magotsiou (2009) state that pupils in their study felt statistically significantly better about individual learning than group learning, as they expressed discomfort with the implementation of elements in group learning.

Frontal teaching via the zoom platform has proven to be a slightly more effective model. Here, pupils achieved slightly higher results $(M=8.09$ minutes) than the individual work in terms of minutes spent in moderate and high-intensity of pupils' activity. Here, we expected even higher values as it was a frontal form of lesson, except that both the pupils and the teacher participated in the work from home. The frontal form of learning makes it easier to control all the children, as we provide instructions (demonstration, explanation, etc.) to all the pupils simultaneously (Zajec, 2009). The negative feature of this form of learning is that it is more difficult to use differentiation and individualisation in this way because the tasks are usually the same for all pupils, which means that some may be too much or too little demanding and do not encourage imagination, independent thinking, curiosity, and creativity (Kavčnik, 2008). In our study, the teacher taught them in a similar way as in school, yet tailored to the situation, with explanations, direct demonstrations and repetition. The problems encountered here included poor visibility of the direct demonstration (e.g., body position (bending backwards, forwards, to the side, etc.), lift height, gaze orientation, etc.), the teachers' inability to observe and correct all pupils' performances at once, negative exposure of each pupil in front of all the classmates when correcting performances, spatial problems in performances, problems with the Internet connection and, consequently, several times, worse communication between teacher 
and pupils. Despite the constant monitoring of pupils by the teachers, which was feasible compared to the previous model, due to the aforementioned obstacles that frontal teaching brings in distance learning of PE, the pupils achieved significantly low values in moderate and high-intensity activity.

Depending on the intensity of activity shown by pupils, frontal teaching was followed by a combination of frontal teaching and group work at stations ( $M=15.19$ minutes). Such a result is already quite high in terms of distance work as when performing work in the sports hall; the goal is to achieve at least $50 \%$ of the time devoted to the PE (at least 22.5 minutes) in moderate and high-intensity activity (Hollis et al., 2016). With distance work, the lessons are shorter (approx. 30 to 35 minutes), so even half of this time spent in moderate and high-intensity activity is a good enough result. This model had similar problems as with frontal distance learning, except that the pupils here were not so negatively exposed as the corrections of their performances were heard in small groups. The advantage of this form of work was that the teacher could first explain the material to everyone and demonstrate the work that awaited the pupils at each station; then, the performances were rehearsed in front of a small group of classmates at their stations or rooms. Next, the teacher randomly divided them into stations, where they remained until the end of the lesson. In the meantime, the teacher joined the rooms, observed their work, gave them additional instructions, motivated them and corrected their performances. After about three to five minutes, the assignments at each station were switched as if the pupils were moving to the next station. In this way, the work was kept interesting and diverse, ensuring the pupils did not start to get bored, and as a result, they reached higher levels of activity intensity. This form of work also allowed teachers to monitor the work of each student quite effectively.

The combination of frontal teaching and group work at stations was followed by the flipped learning teaching model, depending on the intensity of the pupils' activity, in which pupils received material in the form of interactive assignments and games $(M=\mathbf{2 2 . 2 2}$ minutes; the result is the sum of both workdays). Such a teaching model has proven to be the second most effective in achieving high-intensity activity during lessons. Pupils received the learning material through interactive assignments and computer games, which was a great approach to learning. It is largely known that pupils spend too much time in front of computers (Sharma \& Majumdar, 2009), and during the Covid-19 epidemic, this amount of time increased due to compulsory social distancing from their peers (Montag \& Elhai, 2020), and their motivation for classical learning decreased (Dietrich et al., 2020). So, we combined the teaching of materials through interactive assignments and games so that the time they spent playing games 
also brought them some new knowledge. They enjoyed playing computer games (puzzles, composing terminology, connecting words to pictures, rearranging the order of movements and so on, while imitating movements and performing various elements demonstrated through assignments and games, etc.). By solving assignments and playing games, they gained minutes of activity on a day when there is no PE lesson scheduled, but at the same time, they received insight into the next PE lesson and group problem-solving activity with classmates. In the lesson itself, the teacher initially only briefly explained the content of the lesson, which they learned a lot about the day before through games, and then randomly divided them into groups, where they could immediately start solving the task, which they also already got with the assignments and games, so no time was wasted here by giving additional instructions. The pupils solved assignments in groups with movements, so they were active for nearly the entire time of group work; simultaneously, no one was negatively exposed to ignorance, as they all got at least minimal insight through the previous day's assignments. In our action research, such a model has proven to be extremely effective. However, its disadvantage is the large amount of time such preparations took from teachers, as we had to design interactive assignments and games according to the content of each lesson and pass them on to the pupils. Certain problems also occurred with pupils who had older computers and poorer internet connections as newer computer systems only supported certain games.

The statistically significantly most effective model in terms of the number of minutes spent in moderate and high-intensity activity proved to be the flipped learning teaching model, which was organised in the same way as the previously described model, only that the material received in advance by pupils was not in the form of interactive tasks and games, but in the form of videos ( $M=28.15$ minutes; the result is the sum of both days of work). The videos showed a direct demonstration of each element they needed to learn for the upcoming lesson (demonstrations were recorded from different angles and at different speeds of implementation, thus adding differentiation to learning; these could be watched and performed at a slower pace by the weaker ones or at a more demanding faster pace by the stronger ones, and a demonstration of incorrectly performed elements so that pupils would not repeat such mistakes).

Furthermore, the recordings contained music and slipups during the recording sessions, making them more interesting for the pupils, who wanted to replay them several times (their opinions on the performances were also included in the diary records for the intermediate upgrade of teaching preparations). Such a model proved to be the most effective but also the most demanding for teachers to implement. In addition to the large amount of time necessary for 
preparing the implementation of this model (model 5 requires even more time than model 4; about 5-6 hours to edit a recording only 8-10 minutes long, excluding planning and recording), for such preparations, teachers urgently need help with the filming, as the recordings of movements in direct demonstrations of elements are not visible enough.

Based on the stage of the learning process, each PE distance learning model that we studied included lessons that provided new learning material and consolidation, enabling us to compare the effectiveness between them.

\section{Conclusions}

Distance learning of PE has become a special challenge for those who teach this subject, as they bear part of the responsibility to achieve the recommended daily amount of physical activity of individuals, which is extremely important for maintaining health and strengthening the immune system and consequently to combat Covid-19 disease effectively. Recommendations and measures during the epidemic, such as staying at home, closing parks, sports halls, fitness centres and similar, were necessary to curb the spread of the disease but had a significant effect on reducing the recommended daily amount of physical activity of individuals (Siordia Jr., 2020). Of the five distance PE models studied, only two proved to be extremely effective in achieving a sufficient amount of moderate and high-intensity activity, namely the flipped learning teaching model in combination with the material in the form of interactive assignments and games and the flipped learning teaching model in combination with the material in the form of videos. The model involving a combination of frontal teaching and group work at stations also provided satisfactory results as the pupils spent about 50\% of the time of shortened PE distance learning lessons (about 30-35 minutes) in moderate and high-intensity activity.

In the action research, we examined and observed 33 distance-learning PE lessons, in which we introduced five types of distance PE models that we designed based on theoretical models and transferal of teaching practices held in schools. Based on the designed models, we prepared the material and implementation plan for each lesson according to the content with the help of accelerometers and diary records. After conducting the measurements, as the final part of the action research, we presented the concept of working with five PE distance learning models to all PE teachers working at the school. We provided them with data on the intensity of pupil activity in each model, the daily records of lessons taught, interactive tasks with access passwords and instructions on how to design new ones for other content that were not included 
in our research, and videos with notes of how we filmed them ourselves and edited them into meaningful teaching material. Despite good preparation, the research had several limitations, particularly the inclusion of only one school and consequently a smaller sample group, incomplete numerical distribution of lessons concerning each model (the most effective models were studied at the minimum number of lessons) and inequality of learning content among some models (the MET level also depends on the content of exercise and didactic level, which varied in the study), making generalisation limited. Additional research regarding distance teaching of PE will be conducted on a larger sample group with various ages of children and with a larger number of hours for each type of learning content in each model. Distance education is currently a major concern for all teachers as it is unknown how long such a situation will last or when it might recur. For this reason, they must be maximally prepared to conduct effective distance learning lessons. For this reason, in the future, we aim to research and discover the effectiveness of new distance learning models for PE, which we have not been able to include in the current action research.

\section{References}

Betihavas, V., Bridgman, H., Kornhaber, R., \& Cross, M. (2016). The evidence for 'flipping out': A systematic review of the flipped classroom in nursing education. Nurse Education Today, 38, 15-21. https://doi.org/doi:10.1016/j.nedt.2015.12.010 Buschner, C. (2006). Online physical education: Wires and lights in a box. Journal of Physical Education, Recreation \& Dance, $77(2), 3-8$.

Chick, R. C., Clifton, G. T., Peace, K. M., Propper, B. W., Hale, D. F., Alseidi, A. A., ... Vreeland, T. J. (2020). Using technology to maintain the education of residents during the COVID-19 pandemic. Journal of Surgical Education, 77(4), 729-732. https://doi.org/10.1016/j.jsurg.2020.03.018 Colley, R. C., \& Tremblay, M. S. (2011). Moderate and vigorous physical activity intensity cut-points for the Actical accelerometer. Journal of Sport Sciences, 29(8), 783-789. https://doi.org/10.1080/02640 414.2011.557744

Dietrich, N., Kentheswaran, K., Ahmadi, A., Teychené, J., Bessière, Y., Alfenore, S., ... Hébrard, G. (2020). Attempts, successes, and failures of distance learning in the time of COVID-19. Journal of Chemical Education, 97(9), 2448-2457. https://doi.org/10.1021/acs.jchemed.ocoo717 Filiz, B., \& Konukman, F. (2020). Teaching strategies for physical education during the COVID-19 Pandemic. Journal of Physical Education, Recreation \& Dance, 91(9), 48-50. https://doi.org/10.1080/o 7303084.2020 .1816099

Goudas, M., \& Magotsiou, E. (2009). The effects of a cooperative physical education program on students' social skills. Journal of Applied Sport Psychology, 21(3), 356-364.

Guraya, S. (2020). Combating the COVID-19 outbreak with a technology-driven e-flipped classroom 
model of educational transformation. Journal of Taibah University Medical Science, 15(4), 253-254. https://doi.org/10.1080/10413200903026058

Hollis, J. L., Williams, A. J., Sutherland, R., Campbell, E., Nathan, N., Wolfenden, L., ... Wiggers, J. (2016). A systematic review and meta-analysis of moderate-to-vigorous physical activity levels in elementary school physical education lessons. Preventive medicine, $86,34-54$. https://doi. org/10.1016/j.ypmed.2015.11.018

Kavčnik, K. (2008). Interes otrok za izvajanje gibalnih dejavnosti glede na različne oblike dela pri predšolski športni vzgoji [Children's interest in performing physical activities in relation to various forms of work in preschool physical education] (Doctoral dissertation). University of Ljubljana, Faculty of Sports.

Kooiman, B. J., Sheehan, D. P., Wesolek, M., \& Retegui, E. (2017). Moving online physical education from oxymoron to efficacy. Sport, Education and Society, 22(2), 230-246. https://doi.org/10.1080/1357 3322.2015.1015978

Mohnsen, B. (2012). Implementing online physical education. Journal of Physical Education, Recreation \& Dance, 83(2), 42-47. https://doi.org/10.1080/07303084.2012.1059872 Montag, C., \& Elhai, J. D. (2020). Discussing digital technology overuse in children and adolescents during the COVID-19 pandemic and beyond: On the importance of considering affective neuroscience theory. Addictive Behaviors Reports, 12. https://doi.org/10.1016/j.abrep.2020.100313 Mosier, B. (2013). Virtual physical education: A call for action. Journal of Physical Education, Recreation \& Dance, 83(3), 6-10. https://doi.org/10.1080/07303084.2012.10598734 Petretto, D. R., Masala, I., \& Masala, C. (2020). School closure and children in the outbreak of COVID-19. Clinical Practice \& Epidemiology in Mental Health, 16, 189-191. https://doi. org/10.2174/1745017902016010189 Qiu, H., Wu, J., Hong, L., Luo, Y., Song, Q., \& Chen, D. (2020). Clinical and epidemiological features of 36 children with coronavirus disease 2019 (COVID-19) in Zhejiang, China: An observational cohort study. The Lancet Infectious Diseases, 2o(6), 689-696. https://doi.org/10.1016/s1473$3099(20) 30198-5$

Quezada, R. L., Talbot, C., \& Quezada-Parker, K. B. (2020). From bricks and mortar to remote teaching: A teacher education program's response to COVID-19. Journal of Education for Teaching, 46(4), 472-483. https://doi.org/10.1080/02607476.2020.1801330 Rhea, D. J. (2013). Virtual physical education in the K-12 setting. Journal of Physical Education, Recreation \& Dance, 82(1), 5-50. https://doi.org/10.1080/07303084.2011.10598551 Richards, K. A. R., Iannucci, C., McEwoy, E., \& Simonton, A. (2020). The professional socialisation challenge: Teacher education for a preferable future for physical education. Kinesiology and Community Health. In A. MacPhail \& H. Lawson (Eds.), School physical education and teacher education collaborative redesign for the 21st century (pp. 70-81). Routledge.

Sharma, M., \& Majumdar, P. K. (2009). Occupational lifestyle diseases: An emerging issue. Indian Journal of Occupational \& Environmental Medicine, 13(3), 109-112. https://doi.org/10.4103/oo195278.58912 
Siordia Jr., J. A. (2020). Epidemiology and clinical features of COVID-19: A review of current literature. Journal of Clinical Virology, 127, 104357. https://doi.org/10.1016/j.jcv.2020.104357.

Sohrabi, B. \& Iraj, H. (2016). Implementing flipped classroom using digital media: A comparison of two demographically different groups perceptions. Computers in Human Behavior, 6o, 514-524. https://doi.org/10.1016/j.chb.2016.02.056 Varea, V., \& Gonzáles-Calvo, G. (2020). Touchless classes and absent bodies: Teaching physical education in times of Covid-19. Sport, Education and Society, 1-11. https://doi.org/10.108o/13573322.2 020.1791814

Velavan, T. P., \& Meyer, C. G. (2020). The COVID-19 epidemic. Tropical medicine \& international health: TM \& IH, 25(3), 278-180. https://doi.org/10.1111/tmi.13383

Videmšek, M., \& Pišot, R. (2007). Šport za najmlajše [Sports for the youngest]. Faculty of Sports, ports Institute.

Viner, R. M., Russell, S. J., Croker, H., Packer, J., Ward, J., Stansfield, C., ... Booy, R. (2020). School closure and management practices during coronavirus outbreaks including COVID-19: a rapid systematic review. The Lancet Child \& Adolescent Health, 4(5), 397-404. https://doi.org/10.1016/s23524642(20)30095-X Zajec, J. (2009). Povezanost športne dejavnosti predšolskih otrok in njihovih staršev z izbranimi dejavniki zdravega načina življenja [The connection of sports activities of preschool children and their parents with the chosen factors of a healthy lifestyle] (Doctoral dissertation). University of Ljubljana, Faculty of Sports.

\section{Biographical note}

TANJa Petrušič is a teaching assistant in the field of didactics of physical education at the Faculty of Education, University of Ljubljana, Slovenia. Her main areas of research are: efficiency of the physical education teaching process, nutrition and physical activity behavior in school children, movement, exercise-based interventions and healthy lifestyle.

VESNA ŠTEMBNERGER, PhD, is an associate professor in the field of didactics of physical education at the Faculty of Education, University of Ljubljana. Her main research areas are: Quality of Physical Education in Primary School, Physical Activity Breaks as an Important Factor for Healthy Lifestyle of Children and Adolescents and the Role of Physical Education for Children. 